\title{
Estimasi Emisi Gas Rumah Kaca (GRK) Terhadap Konsumsi Energi di Provinsi Bali
}

\author{
Ida Bagus Bawa Adiputra ${ }^{1}$, Rukmi Sari Hartati ${ }^{2}$, Wayan Gede Ariastina ${ }^{3}$
}

\begin{abstract}
Electrical energy is one concerning lives of the people, then provision must be able to ensure the availability of a sufficient number, reasonable prices and good quality. Until now, the use of fossil fuels is still quite high as a primary energy source that is utilized in the process of generating electricity. It has an impact on climate change so that Greenhouse Gases (GHG) arise.

The composition of energy use at the end of the projection (2030) uses LEAP software Household consists of the sector amounted to 5.865,1 GWh, Industrial sector of 490.380,6 GWh, Public (Commercial) sector of 3.547,5 GWh, and from Transportation sector as big as 7.220.937,8 BoE. The projection of GHG emissions using LEAP software shows that emissions in 2030 for the Household sector amounted to 8.9115 million $\mathrm{tCO}_{2} e q$, the Industrial sector amounted to 1212.3964 million $\mathrm{tCO}_{2} e q$, the Transportation sector amounted to 26.2161 million $\mathrm{tCO}_{2} e q$, and when the generation of electricity was 33,0955 million $\mathrm{tCO}_{2}$ eq. So the total GHG emissions generated are 1,280,6196 million $\mathrm{tCO}_{2}$ eq, this amount is an accumulated increase from 2015 of 61.4533 million $\mathrm{tCO}_{2}$ eq. To suppress the amount of increase of that size, efforts need to be made such as promoting the use of environmentally friendly energy. Reduce the use of private vehicles and switch to public transportation. The government must also support by providing environmentally friendly mass transportation facilities.
\end{abstract}

Intisari-Listrik merupakan salah satu energi yang menyangkut hajat hidup orang banyak, maka penyediaannya harus dapat menjamin ketersediaan dalam jumlah yang cukup, harga yang wajar dan mutu yang baik. Hingga saat ini, penggunaan bahan bakar fosil masih cukup tinggi sebagai sumber energi primer yang dimanfaatkan dalam proses pembangkitan energi listrik. Itu berdampak pada perubahan iklim sehingga timbul Gas Rumah Kaca (GRK).

Komposisi penggunaan energi pada akhir proyeksi (2030) menggunakan software LEAP terdiri dari sektor Rumah Tangga sebesar 5.865,1 GWh, sektor Industri sebesar 490.380,6 GWh, sektor Publik (Komersial) sebesar 3.547,5 GWh, dan dari sektor Transportasi adalah sebesar 7.220.937,8 BoE. Adapun proyeksi emisi GRK dengan menggunakan software LEAP menunjukkan emisi pada tahun 2030 untuk sektor Rumah Tangga sebesar 8,9115 juta $\mathrm{tCO}_{2} \mathrm{eq}$, sektor Industri sebesar $1.212,3964$ juta $\mathrm{tCO}_{2} \mathrm{eq}$, sektor Transportasi sebesar 26,2161 juta $\mathrm{tCO}_{2} \mathrm{eq}$, dan saat pembangkitan tenaga listrik sebesar 33,0955 juta $\mathrm{tCO}_{2} \mathrm{eq}$. Jadi total emisi GRK yang dihasilkan adalah 1.280,6196 juta $\mathrm{tCO}_{2} \mathrm{eq}$, jumlah tersebut adalah akumulasi peningkatan dari tahun 2015 sebesar 61,4533 juta $\mathrm{tCO}_{2}$ eq. Untuk menekan jumlah kenaikan sebesar itu, perlu dilakukan upaya seperti menggalakkan penggunaan energi ramah lingkungan.

\footnotetext{
${ }^{1}$ Pegawai di Kementerian ESDM, Ditjen EBTKE, Jl. Pegangsaan Timur No.1, Menteng, Jakarta Pusat tlp: 02139830077; fax:021-31901087; e-mail: ida.bagus@esdm.go.id

${ }^{2,3}$ Dosen S2 Teknik Elektro Fakultas Teknik Universitas Udayana, Kampus Sudirman, Denpasar, Bali. 80232, Tel. 0361-239599 fax. 0361- 701907; email:
} rukmisari@unud.ac.id,w.ariastina@unud.ac.id Ida Bagus bawa Adıputra: Estıması Emısı Gas Kuman ...
Mengurangi penggunaan kendaraan pribadi dan beralih ke transportasi umum. Pemerintah juga harus mendukung dengan menyediakan sarana transportasi masal yang ramah lingkungan.

Kata Kunci- energi, gas, rumah, kaca, lingkungan, transportasi, iklim, industry.

\section{PENDAHULUAN}

Hingga saat ini, penggunaan bahan bakar fosil masih cukup tinggi sebagai sumber energi primer yang dimanfaatkan dalam proses pembangkitan energi listrik. Itu berdampak pada perubahan iklim sehingga timbul Gas Rumah Kaca (GRK). GRK adalah gas yang terkandung dalam atmosfer baik alami maupun antropogenik, yang menyerap dan memancarkan kembali radiasi inframerah. Perubahan iklim yang mengancam dunia menjadi perhatian Pemerintah Republik Indonesia. Berbagai macam cara telah ditempuh oleh Pemerintah guna menekan perubahan iklim tersebut. Salah satu langkah nyata yang dapat diambil adalah dengan menurunkan emisi Gas Rumah Kaca (GRK). Hal tersebut tercantum pada Rencana Aksi Nasional Penurunan Emisi Gas Rumah Kaca (RAN-GRK). Di mana posisi geografis dari Indonesia sangat rentan terhadap dampak dari perubahan iklim [1].

Dalam RAN-GRK tertuang baik secara langsung dan tidak langsung berbagai rencana kerja terkait kegiatan untuk menurunkan emisi gas rumah kaca. Terdapat berbagai macam kegiatan di dalam RAN-GRK, di antaranya yaitu di bidang pertanian, kehutanan dan lahan gambut, energi dan transportasi, industri, pengelolaan limbah dan kegiatan pendukung lainnya [2].

Perhitungan emisi GRK yang dilakukan melalui inventarisasi GRK ini dengan memperhatikan perencanaan pemenuhan kebutuhan energi di Bali sangat penting dilakukan untuk mengetahui seberapa besar penurunan emisi yang sudah dicapai pada sektor energi. Hasil inventarisasi GRK ini selanjutnya dapat dijadikan dasar untuk melakukan evaluasi terhadap keberhasilan dari berbagai macam kegiatan dalam RAN-GRK, termasuk tindakan perbaikan apabila diperlukan.

\section{ANALISA ENERGI DAN GAS RUMAH KACA}

\section{A. Analisis Kebutuhan Energi Listrik}

Proyeksi permintaan dan strategi penyediaan energi listrik merupakan dasar bagi perencanaan energi. Ketika membuat suatu proyeksi, maka dibutuhkan metode baku yang akan digunakan. Terdapat beberapa pendekatan untuk menyusun proyeksi atau perkiraan kebutuhan energi listrik. Metode yang berdasarkan ekonometrika atau teknik statistika banyak digunakan untuk membuat proyeksi kebutuhan dalam waktu

$$
\text { p-ISSN:1693 - 2951; e-ISSN: 2503-2372 }
$$


jangka panjang. Namun, untuk strategi penyediaan energi banyak digunakan teknik optimasi dengan fungsi objektif tertentu [3].

Indikator yang digunakan untuk menghitung efisiensi energi adalah elastisitas pemakaian (konsumsi) energi. Perbandingan antara pertumbuhan konsumsi energi akhir dengan pertumbuhan Produk Domestik Bruto (PDB) disebut elastisitas pemakaian energi.

Elastisitas Energi $=\frac{\text { Pertumbuhan Konsumsi Energi }}{\text { Pertumbuhan PDB (PDRB) }}$

Perbandingan antara jumlah konsumsi energi per volume aktivitas/PDB disebut intensitas energi. Makin rendahnya angka intensitas, maka akan semakin efisien penggunaan energi di sebuah Negara (Ferial, 2011).

Intensitas Energi $=\frac{\text { Volume Pemakaian Energi }}{\text { Volume Aktifitas }}$

\section{B. Analisa Penyediaan Energi}

Terdapat berbagai macam jenis pembangkit tenaga listrik yang saat ini telah ada di seluruh dunia. Namun dari sekian banyak jenis pembangkit yang ada, hanya beberapa yang dikategorikan sebagai pembangkit listrik tenaga termal (panas). Pada umumnya, jenis pembangkitan ini membutuhkan bahan bakar yang berasal dari bahan bakar fosil. Pembangkit listrik jenis termal ini dapat dibagi lagi menjadi beberapa jenis, diantaranya adalah PLTD, PLTG, PLTGU, dan PLTU.

\section{Inventarisasi Emisi GRK}

Inventarisasi GRK dilakukan dengan cara pemantauan dan pengumpulan data aktivitas sumber emisi, serapan GRK termasuk simpanan karbon serta penetapan faktor emisi dan faktor serapan GRK. Kontribusi GRK untuk pemanasan global bergantung pada jenis gasnya, yaitu karbondioksida $\left(\mathrm{CO}_{2}\right)$, methane $\left(\mathrm{CH}_{4}\right)$, dinitro-oksida $\left(\mathrm{N}_{2} \mathrm{O}\right)$, perfluorocarbon (PFC), hydrofluoro-carbon (HFC) dan sulphur-hexafluoride $\left(\mathrm{SF}_{6}\right)$. Dari semua jenis GRK tadi, salah satu yang mempunyai kontribusi terbesar terhadap pemanasan global dan perubahan iklim adalah $\mathrm{CO}_{2}$ [4].

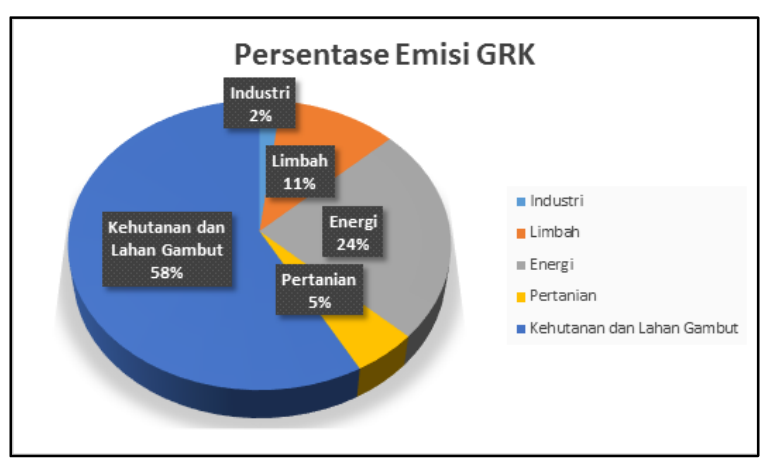

Gambar 1: Persentase Emisi GRK di Indonesia Tahun 2000

Pemantauan dan pengumpulan data aktivitas sumber emisi dan serapan GRK termasuk simpanan karbon, serta penetapan faktor emisi dan faktor serapan. Penghitungan emisi dan serapan GRK termasuk simpanan karbon.

Emisi dan serapan GRK termasuk simpanan karbon dilakukan dengan menggunakan beberapa data, diantaranya adalah:

a) Aktivitas masing-masing sumber emisi dan penyerapannya termasuk simpanan karbon;

b) Aktivitas pada tahun yang sama;

c) Menggunakan faktor emisi dan faktor serapan lokal.

\section{Permodelan LEAP (Long-range Energi Alternatives Planning Sistem)}

Merupakan suatu program permodelan yang dapat digunakan untuk mengetahui permintaan dan suplai energi, sehingga dampak dari produksi kelistrikan berdasar jenis, sumber yang digunakan, biaya sistem serta pemanasan global dapat dicari. Dalam pengembangannya, terdapat pemilihan skenario untuk membandingkan pembangkit dengan sistem energi alternatif mulai dari waktu jangka menengah hingga jangka panjang, sehingga diperoleh analisa dampak keekonomian dan lingkungannya [5].

\section{Analisis Permintaan Energi Final (Final Energi Demand Analysis)}

Salah satu metode yang diperoleh dari hasil perkalian antara aktivitas total pemakaian energi dengan intensitas energi pada tiap cabang teknologi. Untuk persamaan matematika dalam menghitung permintaan dengan analisa permintaan energi final, adalah:

$\mathrm{D}_{\mathrm{b}, \mathrm{s}, \mathrm{t}}=\mathrm{TA}_{\mathrm{b}, \mathrm{s}, \mathrm{t}} \times \mathrm{EI}_{\mathrm{b}, \mathrm{s}, \mathrm{t}}$

dalam penjabarannya, D adalah Permintaan, TA adalah aktivitas total, EI adalah Intensitas Energi, b adalah cabang, s adalah skenario, dan $\mathrm{t}$ adalah tahun saat melakukan perhitungan (mulai dari tahun dasar hingga tahun akhir perhitungan). Intensitas energi adalah rata-rata konsumsi energi tahunan (Energy Consumption=EC) per unit aktivitas (activity level). Dalam matematika persamaannya menjadi:

$\mathrm{EI}=\frac{\mathrm{EC}}{\text { activity level }}$

\section{Analisis Permintaan Energi Terpakai (Useful Energi Demand Analysis)}

Intensitas energi pada metode ini ditentukan dengan cabang Intensitas Energi Gabungan (Aggregate Energi Intensity Branch), bukan pada cabang teknologi (Technology Branch). Pada tahun dasar, ketika digunakan dua besaran sekaligus (yaitu Final Energy Demand dan Useful Energy Demand), maka intensitas energi untuk tiap cabang teknologi adalah ditunjukkan seperti pada persamaan 5 berikut ini.

$$
\mathrm{UE}_{\mathrm{b}, 0}=\mathrm{EI}_{\mathrm{AG}, 0} \times \mathrm{FS}_{\mathrm{b}, 0} \times \mathrm{EFF}_{\mathrm{b}, 0}
$$

dimana $\mathrm{UE}_{\mathrm{b} .0}$ adalah useful energy intensity cabang $\mathrm{b}$ pada tahun dasar, $\mathrm{EI}_{\mathrm{AG}, 0}$ adalah final energy intensity cabang intensitas energi gabungan pada tahun dasar, $\mathrm{FS}_{\mathrm{b} .0}$ adalah fuel 
share cabang $\mathrm{b}$ pada tahun dasar, dan $\mathrm{EFF}_{\mathrm{b} .0}$ adalah efisiensi cabang b pada tahun dasar.

\section{Skenario (Scenario)}

Dalam penelitian kali ini, skenario yang digunakan adalah Business as Usual (BaU). Skenario BaU sendiri merupakan proyeksi yang berdasar pada anggapan bahwa pertumbuhan konsumsi energi listrik akan berjalan sebagaimana biasanya seperti pada waktu sebelumnya. Penggunaan skenario $\mathrm{BaU}$ dapat dilakukan dengan cara memilih Refference (REF) pada kotak Scenario. Setelah itu akan muncul tampilan yang mengharuskan untuk memasukkan data expression. Data masukan adalah data pertumbuhan intensitas energi listrik dan pertumbuhan pelanggan masing-masing sektor tarif [2]. Dalam skenario BaU yang digunakan ini lebih mudah jika diaplikasikan pada program LEAP. Karena pada program tersebut sudah menyediakan pilihan skenario BaU dan Frozen Policy. Apabila ingin menambah skenario lain, misalkan RUED, maka kita diharuskan untuk menghitung terlebih dahulu (di program Microsoft excel) sebelum memasukkan data ke program LEAP.

\section{E. Metode Perhitungan Emisi}

Emisi dari suatu kegiatan secara umum dihitung menggunakan data aktivitas dikalikan dengan faktor emisi dari kegiatan atau bahan tersebut [6].

Emisi $=$ data aktivitas $\mathrm{x}$ faktor emisi $\mathrm{x}$ faktor oksidasi

\section{Dengan:}

Data aktivitas $(\mathrm{DA})=$ data yang menunjukkan besaran aktivitas manusia yang menghasilkan emisi pada kurun waktu tertentu. Biasanya diasosiasikan dengan jumlah bahan bakar (cair, padat hingga gas) yang mengalami proses pembakaran.

Faktor emisi (FE) = koefisien yang mengaitkan DA dengan jumlah senyawa kimia yang merupakan sumber emisi, ton $\mathrm{CO}_{2}$ per aktivitas.

Faktor oksidasi $(\mathrm{FO})=$ persentase jumlah karbon dalam bahan bakar yang mengalami oksidasi dalam proses pembakaran. Umumnya dianggap bahwa seluruh karbon teroksidasi dengan sempurna $\mathrm{FO}=1$.

\section{F. Kondisi Kependudukan, Ekonomi, dan Ketenagalistrikan Provinsi Bali}

Bali merupakan salah satu Provinsi di Indonesia yang dikenal dengan sebutan Pulau Dewata (paradise island). Provinsi ini terletak di antara Pulau Jawa dan Pulau Lombok. Ibukota dari Provinsi Bali adalah Denpasar dengan luas wilayah sekitar $127,88 \mathrm{~km}^{2}$ dan terletak di bagian selatan pulau ini. Secara astronomis, Provinsi Bali terletak pada titik koordinat $08^{\circ} 03$ '40" - 08 50 '48" Lintang Selatan dan $114^{\circ} 25^{\prime} 53^{\prime \prime}$ - $115^{\circ} 42^{\prime} 40^{\prime \prime}$ Bujur Timur yang membuatnya beriklim tropis seperti wilayah lain di Indonesia. Untuk batas wilayahnya, di sebelah utara adalah Laut Bali, di sebelah selatan ada Samudera Hindia, di barat adalah Selat Bali dan di timur berbatasan dengan Selat Lombok [8].

Berdasarkan angka proyeksi penduduk tahun 2016 tercatat jumlah penduduk di Bali sebanyak 4.200,1 ribu jiwa yang

Ida Bagus Bawa Adiputra: Estimasi Emisi Gas Rumah ... terdiri dari 2.115,0 ribu jiwa $(50,36 \%)$ penduduk laki-laki dan $2.085,1$ ribu jiwa $(49,64 \%)$ penduduk perempuan. Jumlah penduduk ini naik dari tahun sebelumnya, yaitu 4.152,8 ribu jiwa (naik 1,14\%) [8].

Pada tahun 2017, beban puncak dari sistem tenaga listrik di Provinsi Bali sebesar 852MW yang terjadi pada bulan November. Pasokan daya dari kabel laut Jawa-Bali 400MW dan pembangkit $150 \mathrm{kV}$ sebesar $1.042 \mathrm{MW}$ yang terdiri dari pembangkit BBM 408MW, pembangkit LNG/BBM 208MW, dan PLTU Celukan Bawang 426MW.

Untuk realisasi penjualan tenaga listrik dan jumlah pelanggan pada tahun 2011 sampai dengan 2016 serta estimasi tahun 2017 per sektor pelanggan di Provinsi Bali ditunjukkan pada tabel I dan tabel II.

TABEL I

REALISASI PENJUALAN TENAGA LISTRIK

\begin{tabular}{|c|l|r|r|r|r|r|r|r|}
\hline No. & $\begin{array}{l}\text { Kelompok } \\
\text { Pelanggan }\end{array}$ & $\mathbf{2 0 1 1}$ & $\mathbf{2 0 1 2}$ & $\mathbf{2 0 1 3}$ & $\mathbf{2 0 1 4}$ & $\mathbf{2 0 1 5}$ & $\mathbf{2 0 1 6}$ & $\mathbf{2 0 1 7}$ \\
\hline 1 & $\begin{array}{l}\text { Rumah } \\
\text { Tangga }\end{array}$ & 1.420 & 1.548 & 1.661 & 1.847 & 1.918 & 2.105 & 2.129 \\
\hline 2 & Bisnis & 1.482 & 1.645 & 1.860 & 2.059 & 2.226 & 2.510 & 2.556 \\
\hline 3 & Publik & 206 & 228 & 245 & 269 & 282 & 305 & 310 \\
\hline 4 & Industri & 116 & 126 & 148 & 160 & 168 & 179 & 176 \\
\hline \multicolumn{2}{r|r}{ Jumlah } & 3.224 & 3.547 & 3.914 & 4.335 & 4.594 & 5.099 & 5.170 \\
\hline \multicolumn{2}{r}{ Pertumbuhan (\%) } & 4,30 & 10,01 & 10,37 & 10,75 & 5,98 & 10,99 & 1,39 \\
\hline
\end{tabular}

TABEL II

REALISASI JUMLAH PELANGGAN (RIBU)

\begin{tabular}{|c|l|c|r|r|r|r|r|r|}
\hline No. & $\begin{array}{l}\text { Kelompok } \\
\text { Pelanggan }\end{array}$ & $\mathbf{2 0 1 1}$ & $\mathbf{2 0 1 2}$ & $\mathbf{2 0 1 3}$ & $\mathbf{2 0 1 4}$ & $\mathbf{2 0 1 5}$ & $\mathbf{2 0 1 6}$ & $\mathbf{2 0 1 7}$ \\
\hline 1 & $\begin{array}{l}\text { Rumah } \\
\text { Tangga }\end{array}$ & 729,2 & 791,3 & 856,5 & 920,2 & 975,1 & $1.019,9$ & $1.091,4$ \\
\hline 2 & Bisnis & 80,4 & 93,2 & 109,2 & 133,1 & 168,2 & 193,2 & 192,6 \\
\hline 3 & Publik & 28,5 & 30,3 & 32,3 & 35,1 & 37,6 & 40,6 & 43,9 \\
\hline 4 & Industri & 0,65 & 0,67 & 0,71 & 0,76 & 0,80 & 0,97 & 1,17 \\
\hline \multicolumn{2}{|l|}{ Jumlah } & 839 & 916 & 999 & 1.089 & 1.182 & 1.255 & 1.329 \\
\hline Pertumbuhan (\%) & 7,00 & 9,16 & 9,09 & 9,06 & 8,49 & 6,17 & 5,93 \\
\hline
\end{tabular}

\section{METODOLOGI PENELITIAN}

\section{A. Simulasi menggunakan LEAP}

Dalam melakukan simulasi pada LEAP, perlu melihat kembali data yang dimiliki. Hal tersebut sangat memungkinkan, karena permodelan LEAP mempunyai fleksibilitas tinggi sehingga memberi keleluasaan bagi penggunanya. Permodelan LEAP dapat diatur sesuai data yang dimiliki. Jika data yang ada sangat terbatas seperti simulasi pada penelitian ini, dimana hanya memiliki data yang berkaitan dengan konsumsi energi listrik saja itu sudah bisa digunakan.

\section{B. Metode simulasi}

Dalam simulasi ini digunakan metode yang berdasar pada analisis permintaan energi final atau dikategorikan model enduse. 


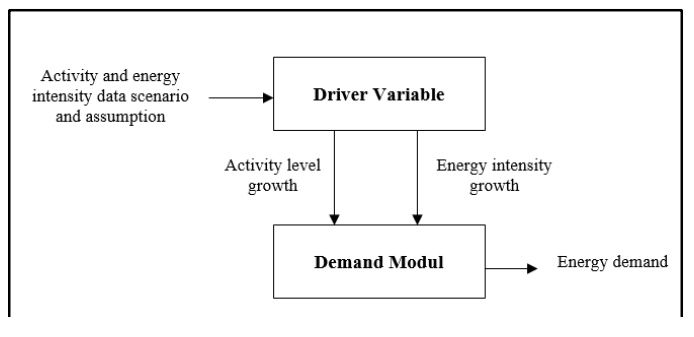

Gambar 2: Bagan simulasi

\section{Parameter dasar}

Langkah awal dalam melakukan simulasi adalah mengatur dan menentukan parameter dasar simulasi. Parameter dasar simulasi hanya dalam lingkup analisis permintaan (demand). Kemudian menentukan tahun dasar simulasi. Dalam penelitian ini, tahun dasar yang digunakan adalah tahun 2015. Kemudian menentukan tahun pertama berlakunya skenario, yaitu tahun 2016 dan batas akhir periode simulasi, yaitu tahun 2030. Lalu yang terakhir adalah menentukan unit satuan yang digunakan seperti unit energi dan mata uang.

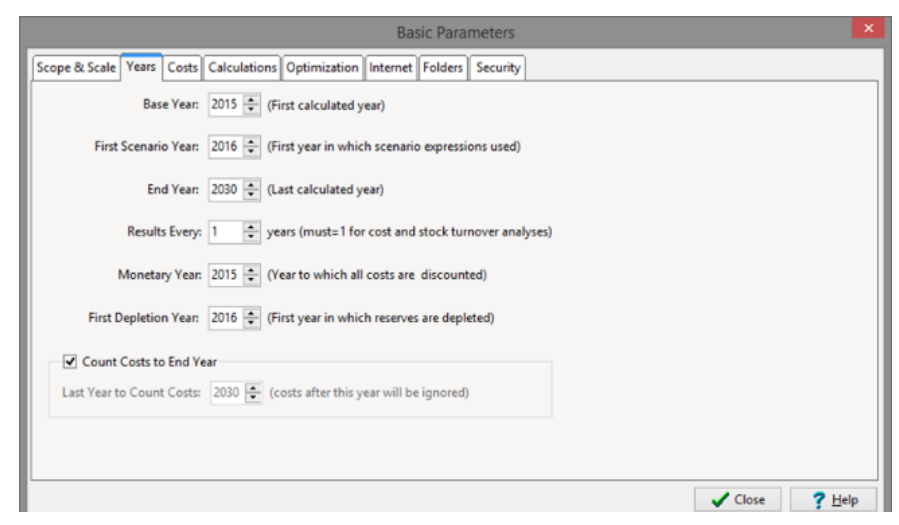

Gambar 3: Parameter dasar dalam LEAP

\section{Analisis Permintaan}

Ini adalah cabang yang paling menentukan bagaimana karakteristik perhitungan dari permintaan nantinya. Permodelan proyeksi pemakaian energi listrik oleh pelanggan PLN (energi terjual) dibagi ke dalam 4 (empat) kelompok pelanggan, yaitu:

a. Kelompok rumah tangga, adalah penjumlahan golongan tarif S-1, R-1, R-2, dan R-3.

b. Kelompok bisnis, adalah penjumlahan golongan tarif B-1, B-2, B-3, T, C dan tarif Multiguna/Layanan Khusus.

c. Kelompok industri, adalah penjumlahan golongan tarif I-1, I-2, I-3, dan I-4.

d. Kelompok publik, adalah penjumlahan kelompok sosial, gedung kantor pemerintah, dan penerangan jalan umum yaitu golongan tarif S-2, S-3, P-1, P-2, dan P-3.

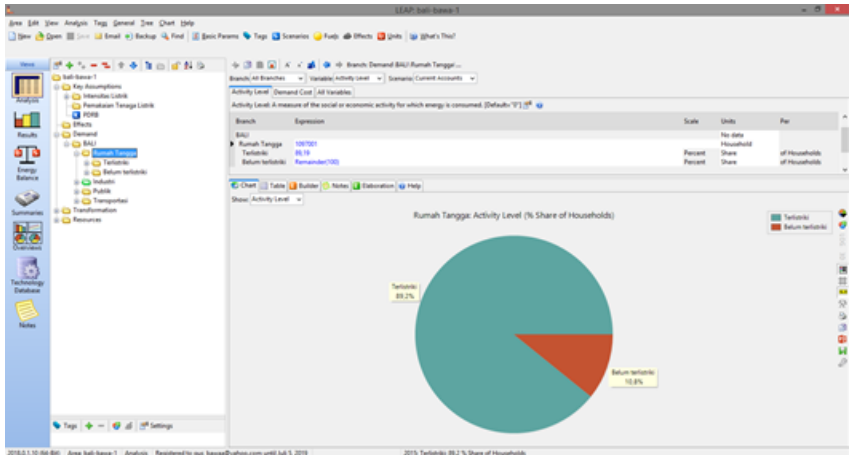

Gambar 4: Ekspresi pada simulasi LEAP

Cabang-cabang yang disusun pada permodelan menggunakan LEAP disesuaikan dengan kelompok pelanggan PLN. Kelompok pelanggan ini dijadikan sebagai nama cabang di modul demand pada LEAP.

\section{E. Skenario (Scenario)}

Setelah mengisi data current account, maka perlu menentukan skenario yang digunakan. Dalam penelitian kali ini menggunakan skenario Business As Usual (BaU). BaU merupakan skenario dimana proyeksi didasarkan pada anggapan bahwa pertumbuhan konsumsi listrik akan berjalan sebagaiman mestinya seperti waktu sebelumnya. Saat menggunakan skenario $\mathrm{BaU}$, kita dapat memilih reference (REF) di kotak skenario. Kemudian akan muncul tampilan yang mengharuskan kita untuk mengisi data ekspresi.

\section{IV.HASIL DAN PEMBAHASAN}

\section{A. Perhitungan Baseline Emisi GRK}

Perhitungan baseline berdasarkan asumsi kenaikan intensitas energi dan jumlah pelanggan PT. PLN dalam periode proyeksi dianggap sama dengan kenaikan rata-rata intensitas energi tahun 2008 hingga 2018. Skenario menggambarkan kondisi ke depan yang tidak berubah terhadap kondisi tahun dasar, yaitu 2015. Proyeksi intensitas energi diperoleh dari pembagian antara penjualan tenaga listrik (tabel III) dengan jumlah pelanggan (tabel IV). Berikut adalah hasil proyeksi intensitas energi dan jumlah pelanggan PLN Provinsi Bali tahun 2018 sampai dengan tahun 2030.

TABEL III

PROYEKSI PENJUALAN TENAGA ListRIK (GWH) Di BALI

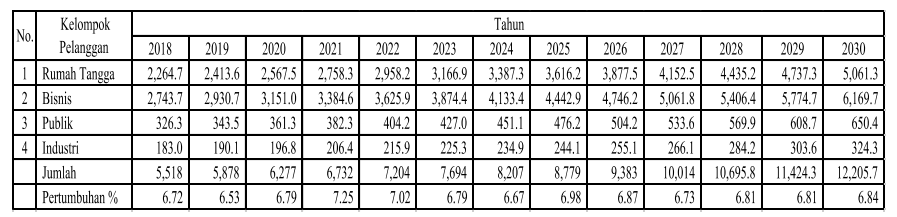

Tabel proyeksi penjualan di atas merupakan data dari RUPTL PT. PLN tahun 2018 sampai dengan 2027. Sedangkan untuk tiga tahun berikutnya dihitung berdasar rata-rata persentase pertumbuhan dari tiga tahun sebelumnya. Begitu pula dengan tabel proyeksi jumlah pelanggan di bawah ini. 
TABEL IV

PROYEKSI JUMLAH PELANGGAN (RIBU)
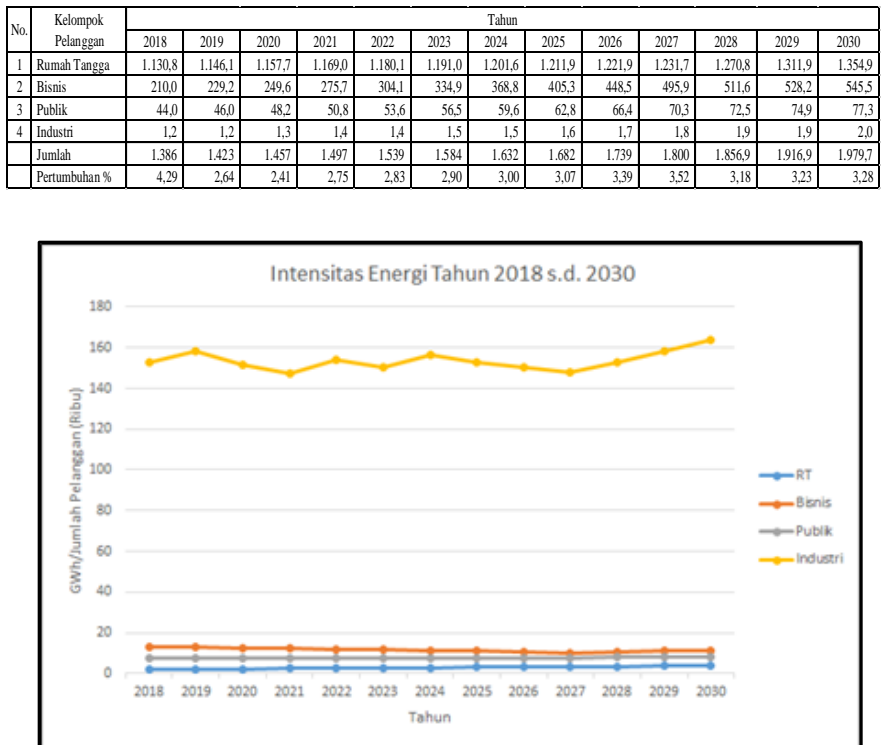

Gambar 5: Proyeksi intensitas energi Provinsi Bali 2018 s.d. 2030

\section{B. Rencana Pembangunan Pembangkit Listrik di Provinsi Bali}

Sebagai tujuan wisata, Provinsi Bali memiliki potensi energi baru dan terbarukan yang dapat dikembangkan untuk pembangkit tenaga listrik yang terdiri dari potensi panas bumi sebesar 354MWe [7]. Potensi panas bumi tersebut berada pada 6 lokasi, yaitu Banyuwedang Buleleng, Seririt Buleleng, Batukao Tabanan, Penebel Tabanan dan Buyan-Bratan Buleleng serta Kintamani-Batu. Selain itu terdapat pula potensi tenaga air sebesar $30 \mathrm{MW}$, potensi tenaga surya sebesar 1MWp yang rencananya akan dilakukan studi PLTS di Pemaron [7].

Untuk rencana pembangunan pembangkit sesuai dengan RUPTL PT. PLN 2018-2027 dapat dilihat pada tabel 4.3 berikut ini:

TABEL V

RINCIAN RENCANA PEMBANGUNAN PEMBANGKIT

\begin{tabular}{|c|c|c|c|c|c|c|c|}
\hline No. & Sistem & Jenis & $\begin{array}{c}\text { Lokasi/Nama } \\
\text { Pembangkit }\end{array}$ & $\begin{array}{c}\text { Kapasitas } \\
\text { (MW) }\end{array}$ & $\begin{array}{l}\text { Target } \\
\text { COD }\end{array}$ & Status & Pengembang \\
\hline 1 & Jawa-Bali & PLTS/B & Tersebar & 25 & 2020 & Pengadaan & IPP \\
\hline 2 & Jawa-Bali & PLTS/B & Tersebar & 25 & 2020 & Pengadaan & IIPP \\
\hline 3 & Jawa-Bali & PLTBm & Tersebar & 1 & 2022 & Rencana & Unallocated \\
\hline 4 & Jawa-Bali & PLTSa & Tersebar & 15 & 2022 & Rencana & Unallocated \\
\hline 5 & Jawa-Bali & PLTU/GU/MG & Bali & 135 & 2022 & Rencana & Unallocated \\
\hline 6 & Jawa-Bali & PLTS/B & Tersebar & 25 & 2023 & Rencana & IPP \\
\hline 7 & Jawa-Bali & PLTS/B & Tersebar & 25 & 2023 & Rencana & IIPP \\
\hline 8 & Jawa-Bali & PLTP & Tersebar & 10 & 2025 & Rencana & Unallocated \\
\hline 9 & Jawa-Bali & PLTP & Tersebar & 55 & 2025 & Rencana & Unallocated \\
\hline \multicolumn{4}{|c|}{ Jumlah } & 316 & & & \\
\hline
\end{tabular}

\section{Estimasi Emisi Gas Rumah Kaca}

Dalam penelitian kali ini, emisi gas rumah kaca yang dihitung adalah emisi yang dihasilkan dari pembangkit listrik yang dikelola PLN dan berada di Provinsi Bali. Selain itu juga penggunaan energi khususnya di rumah tangga, industri di Provinsi Bali dan dampak dari penggunaan kendaraan bermotor (alat transportasi).

Ida Bagus Bawa Adiputra: Estimasi Emisi Gas Rumah ...
TABEL VI

PROYEKSI EMISI GRK LIMA TAHUNAN DENGAN PERSENTASE (RIBU METRIC TONNES $\mathrm{CO}_{2}$ EQUIVALENT)

\begin{tabular}{|c|c|c|c|c|c|}
\hline \multirow{2}{*}{ Branches } & \multicolumn{4}{|c|}{ Tahun } & \multirow{2}{*}{ Persentase } \\
\hline & 2015 & 2020 & 2025 & 2030 & \\
\hline Demand & $61.453,0$ & $398.385,4$ & $790.696,8$ & $1.247 .524,1$ & - \\
\hline BALI & $61.453,0$ & $398.385,4$ & $790.696,8$ & $1.247 .524,1$ & - \\
\hline Rumah Tangga & 411,2 & $2.723,0$ & $5.523,7$ & $8.911,5$ & $0,70 \%$ \\
\hline Industri & $59.627,9$ & $386.764,3$ & $768.034,5$ & $1.212 .396,4$ & $94,67 \%$ \\
\hline Transportasi & $1.413,9$ & $8.898,0$ & $17.138,6$ & $26.216,1$ & $2,05 \%$ \\
\hline Trans formation & 0.3 & 3.460 .8 & $17.016,3$ & 33.095 .5 & - \\
\hline Pcmbangkit Listrik & 0,3 & $3.460,8$ & $17.016,3$ & $33.095,5$ & - \\
\hline Processes & 0,3 & $3.460,8$ & $17.016,3$ & $33.095,5$ & $2,58 \%$ \\
\hline
\end{tabular}

Tabel di atas merupakan detail penghasil emisi GRK dari pengguna energi di Provinsi Bali. Nilai yang tercantum pada tabel tersebut dalam satuan unit: Thousand Metric Tonnes $\mathrm{CO}_{2}$ Equivalent. Dari tabel di atas terlihat bahwa penyumbang emisi GRK terbesar ada pada penggunaan energi di Industri. Di-mana pada tahun 2030, emisi GRK yang dihasilkan oleh pengguna energi di Industri mencapai $1.212,4$ juta $\mathrm{tCO}_{2}$ eq. Nilai tersebut adalah $94,67 \%$ dari total emisi GRK yang dihasilkan di Provinsi Bali. Mengapa sektor Industri? Karena Bali merupakan tujuan wisatawan, baik itu dari dalam maupun luar negeri. Jadi untuk mendukung sektor industri pariwisata, selain dibangun hotel, banyak dibangun yang namanya "home stay" untuk daerah-daerah yang cukup jauh dari perkotaan. Dari pengguna energi di hotel dan home stay itulah yang menghasilkan sangat banyak emisi GRK.

Laju pertumbuhan emisi GRK akan sangat berbahaya jika tidak ada usaha dalam menurunkannya. Dengan makin curamnya grafik yang diperoleh, akan memberi dampak yang cukup signifikan bagi perubahan iklim. Peningkatan tajam diperoleh karena emisi yang dihasilkan pada pembakaran batu-bara dalam pembangkitan tenaga listrik lebih besar dibandingkan dengan energi lain.

Dalam Peraturan Presiden RI No. 61 Tahun 2011 tentang Rencana Aksi Nasional Penurunan Emisi Gas Rumah Kaca menyebutkan bahwa kebijakan yang dilaksanakan untuk menunjang RAN-GRK adalah:

1. Peningkatan penghematan energi

2. Penggunaan bahan bakar yang lebih bersih (fuel switching)

3. Peningkatan penggunaan energi baru dan terbarukan (EBT)

4. Pemanfaatan teknologi bersih baik untuk pembangkit listrik maupun sarana transportasi

5. Pengembangan transportasi massal nasional yang rendah emisi, berkelanjutan, dan ramah lingkungan

\section{KESIMPULAN DAN SARAN}

\section{A. Kesimpulan}

Komposisi penggunaan energi pada akhir proyeksi (2030) menggunakan software LEAP terdiri dari sektor Rumah Tangga sebesar 5.865,1 GWh, sektor Industri sebesar 490.380,6 GWh, sektor Publik (Komersial) sebesar 3.547,5 GWh, dan dari sektor Transportasi adalah sebesar 7.220.937,8 BoE. Adapun proyeksi emisi GRK dengan menggunakan software LEAP menunjukkan emisi pada tahun 2030 untuk sektor Rumah Tangga sebesar 8,9115 juta tCO2eq, sektor p-ISSN:1693 - 2951; e-ISSN: 2503-2372 
Industri sebesar 1.212,3964 juta tCO2eq, sektor Transportasi sebesar 26,2161 juta tCO2eq, dan saat pembangkitan tenaga listrik sebesar 33,0955 juta tCO2eq. Jadi total emisi GRK yang dihasilkan adalah 1.280,6196 juta tCO2eq, jumlah tersebut adalah akumulasi peningkatan dari tahun 2015 sebesar 61,4533 juta tCO2eq. Untuk menekan jumlah kenaikan sebesar itu, perlu dilakukan upaya seperti menggalakkan penggunaan energi ramah lingkungan. Mengurangi penggunaan kendaraan pribadi dan beralih ke transportasi umum. Pemerintah juga harus mendukung dengan menyediakan sarana transportasi masal yang ramah lingkungan.

Emisi GRK Jawa, Bali dan Nusa Tenggara pada tahun 2027 sesuai dengan RUPTL yaitu sebesar 250,7 juta tCO2eq. Bila dibandingkan dengan apa yang sudah penulis proyeksikan, hingga 2027 di Bali hanya menghasilkan emisi sebesar 23,4 juta tCO2eq dari segi pembangkitan tenaga listrik. Itu hanya 9,3\% dari total jumlah emisi di Jawa, Bali dan Nusa Tenggara.

Upaya pemenuhan kebutuhan energi di Provinsi Bali ternyata belum mendukung komitmen Pemerintah RI dalam hal penurunan emisi GRK. Pemerintah menargetkan pada tahun 2020 penurunan emisi GRK Nasional sebesar 26\% atas upaya sendiri. Pada tahun 2020 di Bali menghasilkan emisi GRK sebesar 15,29\% jika dihitung dari tahun 2015.

\section{B. Saran}

Lebih diperluas inventarisasi emisi GRK di berbagai sektor yang ada di Provinsi Bali. Inventarisasi tersebut hendaknya dilakukan secara rutin tiap tahunnya, sehingga memperoleh hasil yang optimal.

Peningkatan kerja-sama antara lingkungan Kementerian yang ada di pemerintahan, sehingga memperoleh data yang akurat saat melakukan inventarisasi GRK. Tidak lupa juga kerja-sama Pemerintah Daerah setempat dengan PT. PLN dan juga Pemerintah Pusat guna melakukan aksi mitigasi demi tercapainya agenda nasional penurunan emisi GRK tersebut.

Kekurangan/kelemahan dari hasil penelitian ini adalah tingkat level database yang penulis gunakan masih rendah. Misalnya pada kelompok Rumah Tangga itu hanya dibagi menjadi 2 (dua) kategori, yaitu terlistriki dan belum terlistriki. Begitupula dengan penggunaan energinya masih sebatas energi Listrik, LPG, dan Biomass saja. Jadi untuk pengembangan lebih lanjut, dapat penulis sarankan untuk membagi secara rinci kelompok tersebut. Misalnya dalam kategori Rumah Tangga terlebih dahulu dibagi menjadi yang di perkotaan dan desa. Kemudian baru di pilah lagi untuk di kota dan desa tersebut mana yang sudah terlistriki dan belum.

\section{REFERENSI}

[1] Peraturan Presiden Republik Indonesia Nomor 61 Tahun 2011 Tentang Rencana Aksi Nasional Penurunan Emisi Gas Rumah Kaca. Jakarta, 2011.

[2] Setiawan, dkk., Studi Awal Kebutuhan Energi Listrik dan Potensi Pemanfaatan Sumber Energi Terbarukan di Kabupaten Sleman Daerah Istimewa Yogyakarta. Jurusan Teknik Fisika, Fakultas Teknik, Universitas Gadjah Mada. 2010.

[3] Lanang WTP, Ragil., Kajian Perencanaan Permintaan Dan Penyediaan Energi Di Wilayah Daerah Istimewa Yogyakarta Menggunakan Perangkat Lunak LEAP. Jurusan Teknik Fisika Fakultas Teknik Universitas Gadjah Mada. Yogyakarta. 2005.

[4] Diyah K., Tingkat Emisi Gas Rumah Kaca di Kabupaten Indramayu. Jurnal Sains dan Teknologi Mitigasi Bencana, Vol. 12, No. 2, Desember 2017. 2017.

[5] Madeleine McPherson, Bryan Karney., Long-term scenario alternatives and their implications: LEAP model application of Panama's electricity sector. University of Toronto, Department of Civil Engineering, Toronto, Canada M5S 1A4. 2014.

[6] Kementerian Perencanaan Pembangunan Nasional R.I., Pedoman Penyusunan Rencana Aksi Daerah Penurunan Emisi Gas Rumah Kaca, Jakarta. 2011.

[7] Keputusan Menteri ESDM RI No. 1567 K/21/MEM/2018 tentang Pengesahan Rencana Usaha Penyediaan Tenaga Listrik (RUPTL) PT Perusahaan Listrik Negara (PLN PERSERO) Tahun 2018 s.d. 2027.

[8] Badan Pusat Statistik Provinsi Bali. 2017. Provinsi Bali Dalam Angka 2017. 